\section{Écologie et connaissances ethnozoologiques du porc-épic à crête (Hystrix cristata Linnaeus, 1758) dans les réserves de biosphère de la Pendjari et du W au Bénin}

Séraphin Mouzoun

\section{RÉSUMÉ}

Le porc-épic à crête (Hystrix cristata Linnaeus, 1758), espèce nocturne de la famille des hystricidés, est le plus gros des rongeurs du Bénin, discret et peu connu. Il est menacé de disparition à cause des pressions (chasse, destruction des habitats). La présente étude s'est concentrée sur l'écologie de l'espèce et les connaissances endogènes des populations riveraines des réserves de biosphère de la Pendjari et du $W$ du Bénin et leur périphérie. Cette thèse vise à identifier les facteurs environnementaux qui influencent la sélection de l'habitat par l'espèce ainsi qu'à apprécier l'importance socioculturelle de l'espèce au sein des communautés locales. La méthodologie était la description de l'habitat, l'inventaire de $\mathrm{H}$. cristata et l'estimation de l'abondance relative par le suivi des traces. Dans ces réserves, l'inventaire de $H$. cristata a été réalisé à travers la méthode de la " marche de reconnaissance guidée ", basée sur les indices de présence. Des visites systématiques dans les milieux indiqués par les informateurs, ainsi que des tournées nocturnes ont été effectuées. Les données ethnozoologiques ont été collectées par le biais d'entretiens individuels auprès de 260 personnes - pêcheurs, chasseurs, tradithérapeutes, exploitants agricoles. - dans 10 villages riverains. L'étude a combiné des données sur l'habitat, les menaces, les relations socio-économiques et le régime alimentaire. La distribution de $\mathrm{H}$. cristata est corrélée avec les types de sol et de végétation. Ceux-ci ont un effet très marqué et déterminant sur la présence de l'espèce dans un milieu. La savane arbustive (47,6\% des sites d'occurrence) et la formation saxicole $(37,0 \%)$ sont davantage préférées par l'espèce que la savane arborée (12,1\%) et la galerie forestière $(3,3 \%)$. Ces résultats confirment l'existence d'un gradient écologique. Le test de Kruskal-Wallis réalisé indique une différence significative de ces préférences $(p=0,002)$. L'indice de comptage kilométrique calculé est de 2,85 indices $/ \mathrm{km}$. L'espèce évite les altitudes. Quatre catégories d'utilisation de l'espèce sont notées : la plus importante est l'alimentation (100\% des citations), suivie de la pharmacopée $(60,3 \%)$, du commerce $(24,0 \%)$ et de l'ornement (13,1\%). L'espèce est chassée essentiellement pour la consommation au sein du ménage. Le braconnage est la principale pression exercée sur l'espèce. Des actions sont proposées pour sa conservation et sa préservation.

Mots-clés : Hystrix cristata, porc-épic à crête, distribution, caractéristique écologique, rongeur, menaces, savoirs locaux, réserve de biosphère, espèce nocturne, Pendjari, Réserve du W, Bénin.

\section{Ecology and ethnozoological knowledge of the crested porcupine (Hystrix cristata Linnaeus, 1758) in the Pendjari and $\mathbf{W}$ biosphere reserves of Benin}

\section{ABSTRACT}

The crested porcupine (Hystrix cristata Linnaeus, 1758), a discreet and little known nocturnal species of the hystricidae family, is the largest rodent in Benin. It is in danger of extinction due to pressures that include hunting and habitat destruction. This study on the ecology of the species and endogenous knowledge was conducted among populations adjacent to the Pendjari and W Benin biosphere reserves. The thesis aims to identify the environmental factors that influence habitat selection by the species, and to assess its socio-cultural importance for local communities. The methodology included habitat description, an $\mathrm{H}$. cristata inventory and estimation of its relative abundance by tracking indications of its presence. The inventory of $\mathrm{H}$. cristata in the reserves was carried out according to the "guided reconnaissance march" method based on indications of presence. Systematic visits and night tours were conducted in the environments indicated by informants. The ethnozoological data were collected from individual interviews with 260 people in 10 neighbouring villages, who included fishermen, hunters, traditional healers and farmers. The study combined data on habitat, threats, socio-economic relationships and diet. The distribution of $H$. cristata correlates with soil and vegetation types. These have a very marked effect and are determining factors for the presence of the species in a given environment. Shrub savannah $(47.6 \%$ of occurrence sites) and saxicolous formations (37.0\%) are the preferred habitats in savannah $(12.1 \%)$ and forest gallery environments (3.3\%). These results confirm the existence of an ecological gradient. The Kruskal-Wallis test indicates a significant difference $(p=0.002)$. The calculated odometer count is 2.85 indices / $\mathrm{km}$. The species avoids high altitudes. Four categories of use of the species were noted, the most important being for food ( $100 \%$ of citations), medicines $(60.3 \%)$, trade $(24.0 \%)$ and ornaments $(13.1 \%)$. The species is primarily hunted for household consumption. Poaching is the main pressure on the species. We conclude with proposed conservation and preservation measures.

Keywords: Hystrix cristata, crested porcupine, distribution, ecological characteristics, rodent, threats, local knowledge, biosphere reserve, nocturnal species, Pendjari, W Reserve, Benin.

\section{Ecología y conocimientos etnozoológicos del puercoespín crestado (Hystrix cristata Linnaeus, 1758) en las reservas de la biosfera Pendjari y W de Benín RESUMEN}

El puercoespín crestado (Hystrix cristata Linnaeus, 1758), especie nocturna de la familia de los histrícidos, es el mayor roedor de Benín, discreto y poco conocido. Se encuentra en peligro de extinción a causa de la presión ambiental (caza, destrucción de hábitats). El presente estudio detalla la ecología de la especie y los conocimientos endógenos de las poblaciones vecinas de las reservas de la biosfera Pendjari y $W$ de Benín, y su periferia. Esta tesis tiene como objetivo identificar los factores medioambientales que influyen en la selección del hábitat por la especie, así como valorar la importancia sociocultural de la especie en el seno de las comunidades locales. La metodología consiste en la descripción del hábitat, el inventario de $H$. cristata y la estimación de su abundancia relativa mediante el seguimiento de indicios. En estas reservas, el inventario de $H$. cristata se hace con el método de "marcha de reconocimiento guiada», basado en las señales de presencia. Se realizaron visitas sistemáticas a los entornos indicados por los informadores, así como rondas nocturnas. Los datos etnozoológicos se recogieron realizando entrevistas individuales a 260 personas, entre las cuales había pescadores, cazadores, curanderos, agricultores, de 10 pueblos vecinos. El estudio combina datos sobre hábitat, amenazas, relaciones socioeconómicas y régimen alimentario. La distribución de $H$. cristata está correlacionada con los tipos de suelo y de vegetación. Estos tienen un efecto muy marcado y determinante sobre la presencia de la especie en un medio. Esta especie prefiere la sabana arbustiva ( $47,6 \%$ de los lugares de ocurrencia) y la formación saxícola $(37,0 \%)$ a la sabana arbolada $(12,1 \%)$ y la galería forestal $(3,3 \%)$. Los resultados confirman la existencia de un gradiente ecológico. La prueba de Kruskal-Wallis realizada indica una diferencia significativa $(p=0,002)$. El índice de conteo kilométrico calculado es de 2,85 indicios $/ \mathrm{km}$. La especie evita la alta altitud. Se han constatado cuatro categorías de uso de la especie, la más importante es la alimentación (100\% de las citaciones), seguida de la farmacopea $(60,3 \%)$, el comercio $(24,0 \%)$ y el ornamento $(13,1 \%)$. La especie se caza esencialmente para el consumo en los hogares. La caza furtiva es la principal presión ejercida sobre la especie. Se proponen acciones para su conservación y su preservación.

Mots-clés : Hystrix cristata, puercoespín crestado, distribución, característica ecológica, roedor, amenazas, sabores locales, reserva de la biosfera, especie nocturna, Pendjari, Reserva de W, Benín.
Doi : https://doi.org/10.19182/bft2019.340.a31710 Droit d'auteur @ 2019, Bois et Forêts des Tropiques @ Cirad Date de publication : $1^{\text {er }}$ avril 2019 


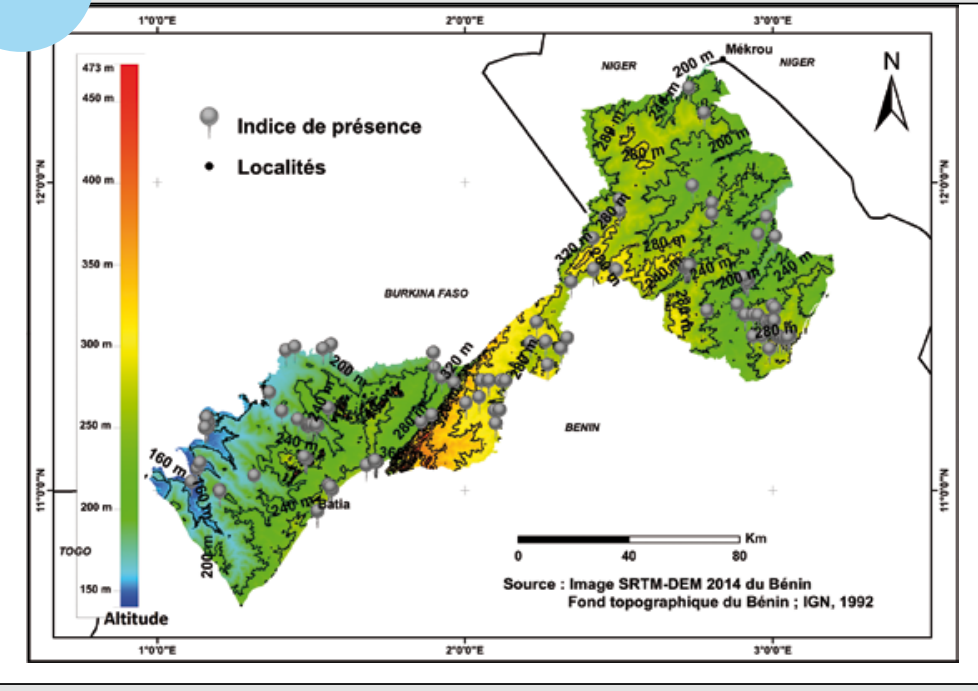

Figure 1.

Carte de répartition des indices de Hystrix cristata en fonction des altitudes. Les plages de couleurs représentent les altitudes et les points gris indiquent la présence de Hystrix cristata. Les altitudes comprises entre 370 et $473 \mathrm{~m}$ sont représentées par la couleur rouge, celles comprises entre 280 et $369 \mathrm{~m}$ figurent en jaune et celles comprises entre 100 et $189 \mathrm{~m}$ en bleu.

\section{Figure 1.}

Distribution of Hystrix cristata according to altitude. Coloured areas show altitudes: $370-473 \mathrm{~m}$ in red, $280-369 \mathrm{~m}$ in yellow and $100-189 \mathrm{~m}$ in blue. Grey dots indicate the presence of $H$. cristata.

\section{Figura 1.}

Mapa de distribución de los índices de Hystrix cristata en función de las altitudes. Las zonas de colores representan las altitudes y los puntos grises representan la presencia de $\mathrm{H}$. cristata. Las altitudes comprendidas entre 370 y 473 m están representadas por el color rojo, las comprendidas entre 280 y 369 m, en amarillo, y las comprendidas entre 100 y 189 m, en azul.

\section{Publications}

Mouzoun S., Lougbegnon T. O., Codjia J. T. C., 2017. Perceptions des causes de disparition du porc-épic à crête de la réserve de biosphère du nord Bénin. Revue de Géographie de l'Université de Ouagadougou, 6 (1) : 103-123.

Mouzoun S., Lougbegnon T. O., Houessou L. G., Codjia J. T. C., 2018. Valorisation du porc-épic à crête (Hystrix cristata) par les communautés des réserves de biosphère de Pendjari et du W (Bénin). Bois et Forêts des Tropiques, 335 : 39-47. https://doi. org/10.19182/bft2018.335.a31498

Mouzoun S., Lougbegnon T. O., Codjia J. T. C., 2018. Pression démographique et conservation de la faune dans les réserves de biosphère du Bénin (Population pressure and wildlife conservation in Benin biosphere). Nature \& Faune, 32 (1) : 82-85.

Mouzoun S., Lougbegnon T. O., Codjia J. T. C., 2018. Étude de quelques aspects écologiques de Hystrix cristata dans les réserves de biosphère du Bénin. In : Actes des Journées scientifiques du Centre béninois de la recherche scientifique et de l'innovation, 181-191.

Grade et diplôme : Docteur en Géosciences de l'Environnement. Université : Université d'Abomey-Calavi, Bénin

Date de soutenance : 7 novembre 2018

\section{Composition du jury}

Direction : Jean T. Claude CODJIA (professeur à l'Université d'Abomey-Calavi, Bénin), Toussaint O. LOUGBEGNON (enseignant à l'Université d'Agriculture, Porto-Novo, Bénin)

Membres : Odile DOSSOU GUEDEGBE (professeur à l'Université d'Abomey-Calavi, Bénin), Edinam KOLA (professeur à l'Université de Lomé, Togo), Tchaa BOUKPESSI (enseignant à l'Université de Lomé, Togo)

\section{Langue de rédaction : français}

\section{Contact}

04 BP 1449, Cadjèhoun-Cotonou, Bénin

seramou@gmail.com

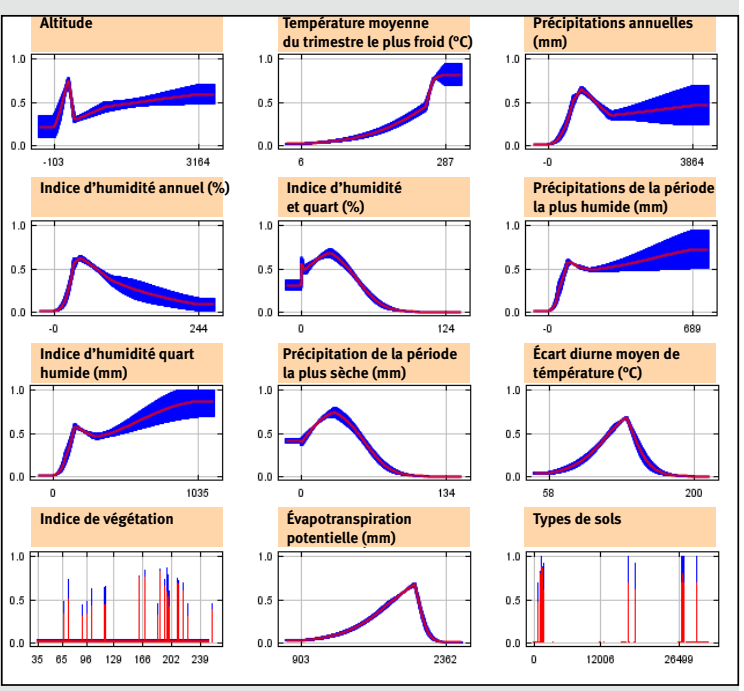

Figure 2.

Relations entre les variables environnementales utilisées pour le modèle et la probabilité de présence de Hystrix cristata dans les réserves de biosphère de la Pendjari et du W au Bénin.

\section{Figure 2.}

Relationships between the environmental variables used for the model and the probability of $H$. cristata presence in the W and Pendjari biosphere reserves in Benin.

Figura 2.

Relaciones entre las variables medioambientales utilizadas para el modelo y la probabilidad de presencia de $H$. cristata crestado en las reservas de biosfera Pendjari y W de Benín.

Photo 1.

Hystrix cristata avec crête caractéristique (délimité par le rectangle rouge).

Photo S. Mouzoun.

Photo 1.

H. cristata showing the characteristic crest (outlined by red rectangle). Photo S. Mouzoun.

Foto 1.

H. cristata con la cresta característica (delimitada por el rectángulo rojo). Foto S. Mouzoun.

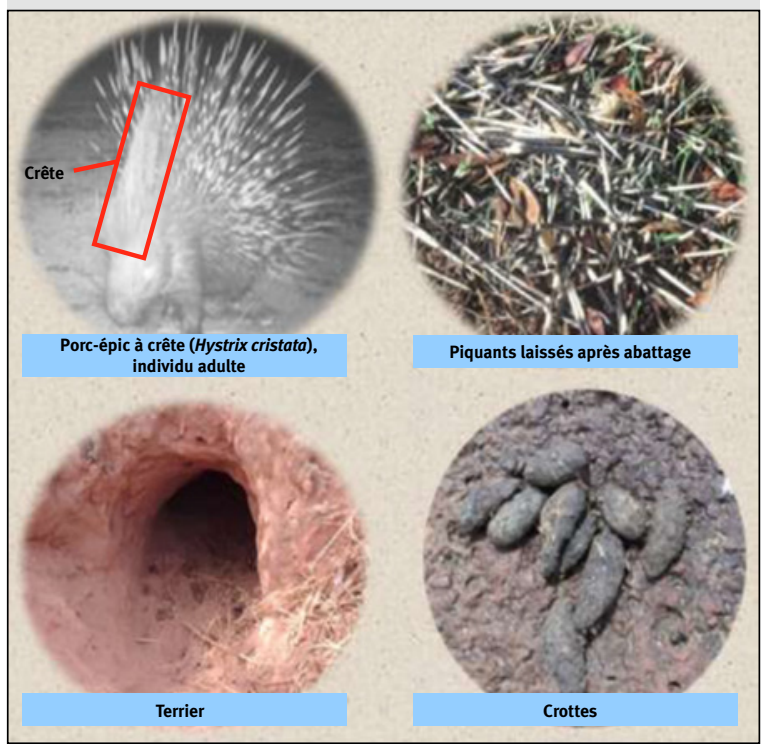

